\title{
EVALUASI PENGAJARAN BAHASA ARAB DENGAN MEDIA ONLINE GOOGLE DI PERGURUAN TINGGI
}

\author{
Dony Ahmad Ramadhani \\ STIQ Amuntai, Hulu Sungai Utara, Kalimantan Selatan \\ Email: Ahmadramadhani77@gmail.com
}

\begin{abstract}
Abstrak
Berdasarkan data dari Effective Measure, 61,88 persen dari pengguna internet Indonesia mengakses melalui ponsel dan dari sumber yang sama didapatkan informasi bahwa pengguna internet di Indonesia di tahun 2011 mencapai 39.100.000 orang (peringkat ke8 di dunia). Dan pada tahun 2018 Indonesia menempati urutan ke 6 sebagai pengguna internet terbanyak di dunia. Maka akan sangat tidak mustahil jika Indonesia nantinya akan menempati urutan di atasnya pada tahun selanjutnya. Hal ini menunjukkan dan mengisyaratkan kepada para pendidik untuk melakukan perubahan terhadap proses pembelajaran dan evaluasi yang berbasis kepada minat siswa agar evaluasi yang tadinya selalu terasa menyeramkan untuk diikuti menjadi evaluasi yang menyenangkan dan akan memberikan kepuasan terhadap siswa dan kemudahan dalam pemberian nilai, karena sifatnya otomatis tanpa harus melakukan pemeriksaan dan hasilnya pun akan langsung dilihat oleh siswa setelah melakukan mengirim jawaban. Terdapat banyak cara dalam pelaksanaan evaluasi berbasis online, dari media yang menggunakan kabel LAN, berbayar, maupun yang gratis. Untuk aplikasi yang dapat digunakan evaluasi secara gratis adalah google form dan google classroom, walaupun disediakan gratis, aplikasi ini memiliki template yang cukup beragam dan menarik. Untuk proses evaluasi pengajaran bahasa Arab sebagai hasil penelitian, pendidik memberikan pengenalan dasar tentang google form dan google classroom sebagai langkah awal, kemudian melakukan persiapan tes yang dapat dilaksanakan dengan dua cara, melakukan input secara langsung menggunakan fitur ketik aplikasi dan menggunakan foto agar bentuk tulisan lebih mudah dibaca, untuk penilaian dilaksanakan dengan memberikan poin dan membatasi waktu pengerjaan dan waktu selesai, sedangkan siswa, hanya cukup membuat akun gmail, melaksanakan tes dan mengirim jawaban
\end{abstract}

Kata Kunci: Evaluasi, Bahasa Arab, Media Online Google

\section{PENDAHULUAN}

Dalam proses pembelajaran, evaluasi merupakan ornament yang sangat urgen dan menentukan keberhasilan siswa, di mana evaluasi oleh sebagian pendidik hanya dianggap formalitas dan bukan merupakan bagian dari proses pembelajaran yang akan berimplikasi kepada kurangnya efektifitas pembelajaran. Dengan mengabaikan evaluasi, maka pendidik secara tidak langsung akan mengabaikan hasil yang ingin dicapai sesuai dengan norma yang berlaku dalam pendidikan, akan terlihat hanya bagaimana siswa dapat lulus 
dan mendapatkan hasil yang diinginkan tanpa adanya pertimbanganpertimbangan dalam hal penjalanan prinsip evaluasi yang baik dan terstruktur. Hasilnya adalah, terjadi berbagai macam kecurangan-kecurangan untuk meluluskan siswa yang seharusnya memang gagal dan tidak diperkenankan untuk melanjutkan ke jenjang berikutnya. Dan peliknya kejadian ini terus menerus berlangsung tanpa hasil yang pasti. Di samping itu juga, evaluasi dipahami hanya sebatas pemberian nilai saja. Padahal jika ditinjau lebih lanjut dan mendalam, evaluasi merupakan sarana perbaikan dan merupakan alat yang dibangun untuk mensukseskan pembelajaran yang menyenangkan dan menenangkan. Dengan adanya pemahaman bahwa evaluasi hanya sebatas pemberian nilai, maka berakibat kepada lalainya guru dalam mempersiapkan evaluasi yang bertujuan untuk mengetahui sejauh mana siswa mampu memahami pelajaran yang telah dia berikan yang mana jika terdapat kekurangan, maka akan dilakukan penyempurnaan. Padahal Pendidikan memiliki ruang lingkup yang luas yang memungkinkan seorang pendidik untuk mengevaluasinya dan melakukan perbaikan atas apa yang sudah diajarkan. ${ }^{1}$ Evaluasi merupakan suatu komponen dan perangkat yang berhubungan dengan tujuan pelajaran, bahan ajar, pelayanan belajar, pendidik, metode dan situasi. ${ }^{2}$ Sehingga evaluasi bukanlah hal dapat dianggap remeh.

Penyempurnaan pembelajaran terbagi menjadi 2 bagian yang tidak akan pernah terpisahkan, (1) Pendidik (2) siswa. Bagi guru, evaluasi dilaksanakan untuk mempertimbangan kemampuan pendidik dalam pembelajaran dengan memikirkan sejauhmana pembelajaran yang telah diberikan sesuai dengan tujuan dari Lembaga yang memberikan tugas kepadanya untuk mengajar, kesesuaian strategi pembelajaran yang dilaksanakan dengan kemampuan siswa, dan kesesuaian materi yang diajarkan. Dan siswa, evaluasi dilaksanakan untuk memberikan pengetahuan kepada para pendidik tentang kekurangan dan kelemahan yang dialami siswa ketika berjalannya proses pembelajaran di kelas, berupa pelajaran apa saja yang masih belum dipahami dan perlu ditekankan akan tidak mempengaruhi materi selanjutnya, dengan begitu akan memberikan sebuah gambaran posisi, dimana siswa berada di antara temantemannya.

Evaluasi yang sampai saat ini banyak dilaksanakan para pendidik banyak memiliki kelemahan; (1) memerlukan waktu yang panjang dan biaya

\footnotetext{
1 Dony Ahmad Ramadhani, "Evaluasi Keterampilan Berbicara Dalam Pembelajaran Bahasa Arab," Al Qalam: Jurnal Ilmiah Keagamaan dan Kemasyarakatan, 2018, h. 79.

${ }^{2}$ Abdul Majid, Strategi Pembelajaran (Bandung: Rosda, 2013), h.26.
} 
yang tidak sedikit untuk memproduksi instrumennya (2) proses pemeriksaan hasil evaluasi yang diikuti siswa cukup rumit dan memerlukan waktu yang lama sehingga cukup membosankan untuk guru (3) proses pengolahan penskoran juga terlihat rumit dan feedback terhadap siswa juga akan memerlukan waktu yang lama (4) secara psikologis, evaluasi manual akan memberikan kecemasan kepada siswa. ${ }^{3}$

Gagalnya siswa dalam pembelajaran pun tidak bisa disalahkan sepenuhnya kepada pendidik, mengingat teknologi yang semakin berkembang dan mempengaruhi anak-anak yang bahkan mampu hidup dengan gadget seharian penuh tanpa harus ke luar rumah. Namun permasalahn tersebut juga tidak lantas memberikan intuisi kepada pendidik untuk berpasrah diri dan bersantai ria. Dengan berkembangnya teknologi, maka pendidik pun harus ikut berperan aktif dalam perkembangan tersebut. Setidaknya pendidik mengarahkan teknologi yang rentan terhadap hal negatif ke arah yang lebih bermakna. Maka dengan adanya teknologi tersebut, guru harus memiliki pengetahuan terupdate dan upgrade keilmuan dalam rangka mempermudah evaluasi, agar terciptanya evaluasi nyaman, instan dan menarik untuk siswa.

Berdasarkan data dari Effective Measure, sebuah firma yang memiliki spesialisasi dalam pengukuran statistik web, sebanyak 61,88 persen dari pengguna Internet Indonesia mengakses melalui ponsel (data tersebut penulis kutip dari situs VIVAnews). Dari sumber yang sama didapatkan informasi bahwa pengguna internet di Indonesia di tahun 2011 mencapai 39.100.000 orang (peringkat ke-8 di dunia). Jika mengacu pada data tersebut, maka pengguna internet mobile di Indonesia adalah sekitar 24.195.080 orang. ${ }^{4}$ Dan sekarang Indonesia menempati urutan ke 6 sebagai pengguna internet terbanyak di dunia. ${ }^{5}$ Dan peningkatan penggunaan internet di Indonesia dari tahun 2013 sampai pada tahun 2018 dapat dilihat dengan tabel yang didapat dari kominfo sebagai berikut:

3 Komang Setemen, "Pengembangan Evaluasi Pembelajaran Online," Jurnal Pendidikan dan Pengajaran 43, no. 3 (2010), h. 1.

${ }^{4}$ Lintang Patria dan Kristianus Yulianto, "Pemanfaatan Facebook untuk Menunjang Kegiatan Belajar Mengajar Online Secara Mandiri," 2011, h. 1-2.

5 PDSI KOMINFO, "Pengguna Internet Indonesia Nomor Enam Dunia," Website Resmi Kementerian Komunikasi dan Informatika RI, diakses 10 Maret 2019, https://kominfo.go.id:443/content/detail/4286/pengguna-internet-indonesia-nomor-enamdunia/0/sorotan_media. 


\begin{tabular}{|c|c|c|c|c|c|c|}
\hline & 2013 & 2014 & 2015 & 2016 & 2017 & 2018 \\
\hline 1. China* & 620.7 & 643.6 & 669.8 & 700.1 & 736.2 & 777.0 \\
\hline 2. Us* & 246.0 & 252.9 & 259.3 & 264.9 & 269.7 & 274.1 \\
\hline 3 inclia & 167.2 & 215.6 & 2523 & 2838 & 313.8 & 346.3 \\
\hline 4. Erazil & 99.2 & 107.7 & 113.7 & 119.8 & 123.3 & 1259 \\
\hline 5. Japan & 1000 & 1021 & 1036 & 1045 & 1050 & 105. \\
\hline 6. Indonesia & 728 & 837 & 934 & 102.8 & 112.6 & 123.0 \\
\hline 7. Russia & 775 & 829 & 87.3 & 91.4 & 94.3 & 960 \\
\hline 8. Germany & 59.5 & 81.6 & 622 & 62.5 & 62.7 & 627 \\
\hline 9. Moxico & $\$ 3.1$ & 59.4 & 65.1 & 70.7 & 75.7 & 80.4 \\
\hline 10. Nigeria & 51.8 & 57.7 & 632 & 69.1 & 76.2 & 84.3 \\
\hline $11.0 \times *$ & 48.8 & 50.1 & 513 & 52.4 & 5.4 & 54.3 \\
\hline 12. France & 48.8 & 49.7 & 505 & 512 & 51.9 & 52.5 \\
\hline 13. Philippines & 42.3 & 48.0 & 53.7 & $\$ 9.1$ & 64.5 & 69.3 \\
\hline
\end{tabular}

\begin{tabular}{|c|c|c|c|c|c|c|}
\hline 14. Turkoy & 36.6 & 410 & 44.7 & 47.7 & 50.7 & 53.5 \\
\hline 15 Vietnam & 36.6 & 40.5 & 44.4 & 48.2 & 52.1 & 55.8 \\
\hline 16. South Korea & 40.1 & 40.4 & 40.6 & 40.7 & 40.9 & 41.0 \\
\hline 17. Esypt & 34.1 & 360 & 38.3 & 40.9 & 43.9 & 47.4 \\
\hline 18. italy & 34.5 & 35.8 & 36.2 & 37.2 & 37.5 & 37.7 \\
\hline 19. Spain & 30.5 & 316 & 323 & 33.0 & 33.5 & 33.9 \\
\hline 20. Canada & 27.7 & 28.3 & 28.8 & 29.4 & 29.9 & 30.4 \\
\hline 21. Argentina & 25.0 & 27.1 & 290 & 29.8 & 30.5 & 31.1 \\
\hline 22. Colombia & 24.2 & 26.5 & 28.6 & 29.4 & 30.5 & 31.3 \\
\hline 23. Thailand & 22.7 & 243 & 260 & 27.6 & 29.1 & 30.6 \\
\hline 24. Poland & 22.6 & 22.9 & 23.3 & 23.7 & 24.0 & 24.3 \\
\hline 25 South Africa & 201 & 227 & 250 & 272 & 29.2 & 30.9 \\
\hline Worldwide.t. & 2.692 .9 & 2.8927 & 3.072 .6 & 3.246 .3 & 3.419 .9 & 3.600 .2 \\
\hline \multicolumn{7}{|c|}{ 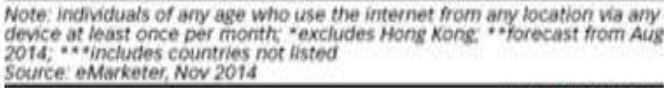 } \\
\hline
\end{tabular}

Sumber: Kominfo.go.id

Kondisi tersebut secara tidak langsung memberikan sebuah insprirasi sekaligus desakan kepada para pendidik untuk mengikuti perkembangan zaman. Karena dengan berkembangnya teknologi yang ada, dapat dimanfaatkan sebagai sarana evaluasi yang efektif dan efisien sesuai dengan minat siswa yang di masa kini terlalu terobsesi dengan gadget dan alat elektronik lainnya.

Peran inovasi pembelajaran akan menciptakan iklim belajar yang akan merangsang motivasi belajar siswa, maka harus dipertimbangkan bahwa evaluasi tidak menjadi ancaman terhadap siswa, namun menjadi kegiatan yang menyenangkan dan menenangkan sesuai dengan minatnya. ${ }^{6}$

Media online yang dijadikan sebagai evaluasi cenderung banyak dan bervariasi, dari membuat aplikasi secara manual sampai aplikasi yang didapatkan secara gratis. Beberapa aplikasi gratis yang sangat mudah diaplikasikan sekarang adalah Google form dan Google Classroom yang dapat diakses dengan mudah menggunakan komputer maupun handphone berbasis android dan IOS. Dengan bebasnya penggunaan tersebut maka akan semakin mempermudah siswa mengikuti proses evaluasi secara tepat dan nyaman. Namun yang perlu diperhatikan adalah, tidak sedikit pendidik dan siswa yang mengalami kesulitan dalam menyesuaikan diri untuk mengikuti perkembangan teknologi evaluasi yang disebabkan kurangnya informasi, baik dari segi kegunaan maupun kemanfaatannya dalam evaluasi.

\footnotetext{
${ }^{6}$ Hamdan Husein Batubara, "Penggunaan Google Form Sebagai Alat Penilaian Kinerja Dosen di Prodi PGMI Uniska Muhammad Arsyad Al Banjari," Jurnal Al Bidayah 8, no. 1 (2016): h. 3.
} 
Secara umum, permasalahan evaluasi berbasis online yang perlu dicarikan solusinya adalah (1) rancangan pembuatan (2) implementasi evaluasi berbasis online. Terkait dengan evaluasi yang ada di Sekolah Tinggi Ilmu AlQur'an masih menggunakan kertas yang rawan dengan borosnya anggaran dan tidak efektifnya proses evaluasi dari segi pengerjaan dan waktu dan belum ada menggunakan evaluasi akhir berbasis online, padahal evaluasi sangat penting dalam pembelajaran yang perlu dipikirkan prosesnya dan kemudahannya.

Media online yang dapat dipakai saat ini dan mudah penggunaannya tanpa harus memikirkan desian yang harus dibuat dan memerlukan waktu yang lama adalah Google form dan Google Classroom yang merupakan besutan dari perusahaan Google, salah satu perusahaan layanan jasa terbesar di dunia. Kedua layanan ini berfungsi sebagai pusat penyimpanan data yang memiliki manfaat secara luas untuk menyimpan data-data hasil ujian/tes, hasil tes secara berkelompok/perkelas, penilaian yang diberikan secara otomatis setalah peserta tes mengupload jawaban dan waktu yang dapat ditentukan berupa waktu mulai dan waktu berakhir secara otomatis, sehingga evaluasi akan menciptakan suasana belajar yang efektif dan efisien tanpa harus mengabaikan perkembangan teknologi yang ada.

\section{METODE PENELITIAN}

Penelitian ini merupakan pengembangan proses belajar yang dulunya hanya berbasis offline dengan menggunakan biaya dan waktu yang relatif besar, maka dengan evaluasi online akan memberikan kemudahan dengan cara menganalisis proses pengenalan dan pelaksanaan evaluasi berbasis online yang dilaksanakan oleh para dosen Sekolah Tinggi Ilmu Al-Qur'an (STIQ) Amuntai di dalam kelas. Penelitian ini merupakan pemanfaatan evaluasi online berbasis google form dan google classroom yang didapatkan secara gratis dari pihak google dan mendukung semua lini elektronik yang dapat diakses melalui internet menggunakan PC, laptop, handphone berbasis android dan IOS. Oleh karena itu, metode yang digunakan adalah metode kualitatif dengan menunjukkan deskripsi terhadap penomena atau tanggapan para pendidik dan siswa mengenai evaluasi online berbasis google form dan google classroom dengan menganalisis data yang didapatkan.

Analisis ini digunakan untuk memberikan sebuah pengetahuan tentang penerapan evaluasi online untuk kalangan pemula oleh para pendidik, baik dari segi produksi data, analisis data, pemantapan data dan penilaian. Proses tersebut nantinya akan di evaluasi dan dianalisis penerapan, kegunaan dan 
pemanfaatannya. Penelitian ini dilaksanakan pada mata pelajaran Pendidikan Bahasa Arab dengan subjek penelitian mahasiswa STIQ Amuntai prodi Pendidikan Bahasa Arab (PBA) dan Pendidikan Guru Madrasah Ibtidaiyah (PGMI) dan unsur pelaksana penerapan evaluasi berbasis online dilakukan oleh Dosen STIQ Amuntai yang dilaksanakan pada tahun 2019. Mekanisme evaluasi online yang dilaksanakan dalam penelitian sebagai berikut:
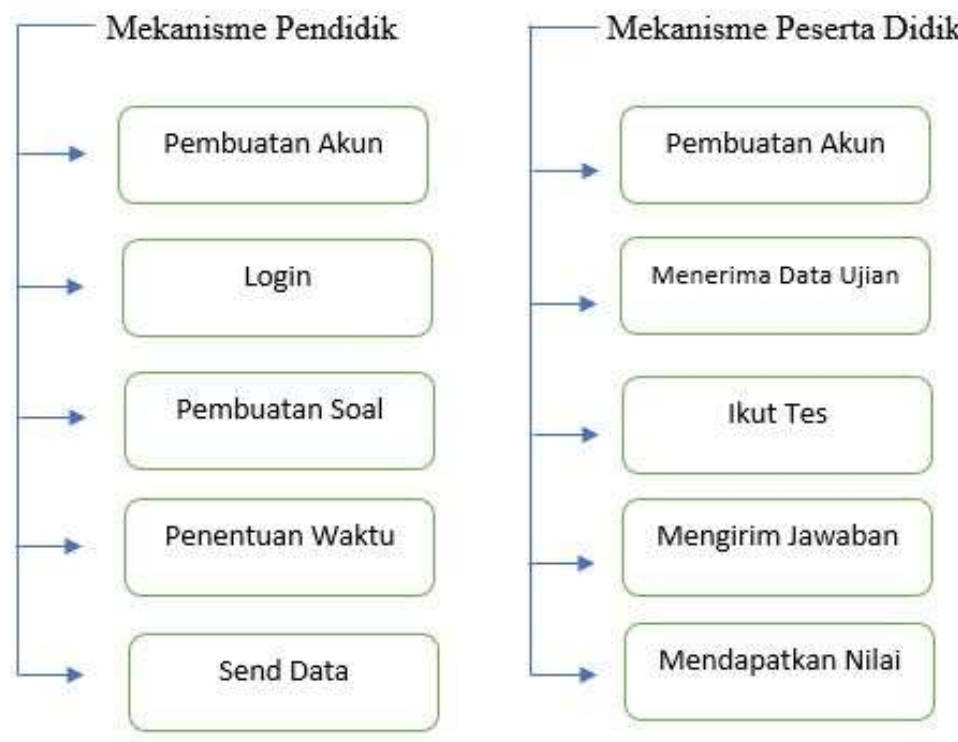

\section{SEKILAS TENTANG GOOGLE FORM DAN GOOGLE CLASSROOM}

Google merupakan salah satu perusahaan jaringan terbesar di dunia, yang bahkan tidak hanya berfokus pada satu lini saja tetapi juga merambah ke dalam dunia pendidikan yang diharapkan dapat memberikan peran aktif dalam melakukan perubahan dunia menjadi lebih baik dan modern, ada dua aplikasi yang setidaknya dapat dimanfaatkan dan memberikan manfaat besar dalam dunia pendidikan; Google form dan Google Classroom.

\section{Google form}

Google form merupakan sebuah layanan yang memungkinkan penggunanya membuat kuis, formulir, maupun survei yang mana fitur ini dapat dibagikan kepada orang lain sesuai dengan keinginan penggunanya. Beberapa keuntungan yang didapat adalah; Tampilan yang cukup menarik dan para 
responden dapat memberikan tanggapan dimana saja tanpa terikat dengan tempat. $^{7}$

Layanan google form telah mengalami beberapa pembaruan selama bertahun-tahun. Fitur-fitur baru tidak terbatas pada pencarian menu, tetapi juga membatasi tanggapan untuk sekali per orang, URL lebih pendek, pembatasan waktu jawaban dan lainnya. Pada Oktober 2014, Google memperkenalkan add-on untuk Formulir Google, yang memungkinkan pengembang pihak ketiga membuat alat baru untuk lebih banyak fitur dalam survei. Pada bulan Juli 2017, Google memperbarui Formulir untuk menambahkan beberapa fitur baru "Validasi respons cerdas" mampu mendeteksi input teks dalam bidang formulir untuk mengidentifikasi apa yang tertulis dan meminta pengguna untuk mengoreksi informasi jika salah memasukkan. Bergantung pada pengaturan berbagi file di Google Drive, pengguna dapat meminta unggahan file dari individu di luar perusahaan masing-masing, dengan batas penyimpanan awalnya sebesar $1 \mathrm{~GB}$, yang dapat diubah menjadi 1 TB. Kotak centang baru memungkinkan jawaban multi-opsi dalam tabel. ${ }^{8}$ Dengan adanya fitur penambahan local drive tentunya para pengguna tidak perlu takut dan berfikir keras jika ternyata local drivenya penuh.

Dalam menggunakan google form setiap pendidik dianjurkan untuk memiliki akun gmail yang juga berasal dari google. Akun email ini dapat dibuat secara gratis/tanpa berbayar. Google sendiri memberikan layanan gratis untuk mengirim, menerima dan pengelolaan data. ${ }^{9}$

\section{Google Classroom}

Dengan adanya google classroom diasumsikan tujuan pembelajaran akan lebih mudah dilaksanakan dan direliasasikan serta memiliki makna yang mendalam. Dengan begitu, penggunaan Google classroom akan mempermudah

${ }^{7}$ Yuyun Mashurwati, "Penerapan inventory tes gaya belajar remaja dengan aplikasi google form, media sosial serta pengembangan program layanan bimbingan dan konseling terkait," Jurnal EDUCATIO: Jurnal Pendidikan Indonesia 4, no. 1 (2018): h.4.

$8 \quad$ "Google Forms," dalam Wikipedia, 21 Februari 2019, https://en.wikipedia.org/w/index.php?title=Google_Forms\&oldid=884340113.

${ }_{9}^{9}$ Muhammad Iqbal dkk., "Penggunaan Google Forms Sebagai Media Pemberian Tugas Mata Kuliah Pengantar Ilmu Sosial," JUPIIS: JURNAL PENDIDIKAN ILMU-ILMU SOSIAL 10, no. 1 (2018): h. 124. 
para pendidik dalam mengelola dan pemberian informasi secara cepat, tepat dan akurat. ${ }^{10}$

Google classroom dalam bahasa Indonesia adalah ruang kelas google, sebuah pembelajaran campuran yang diperuntukkan terhadap setiap ruang pendidikan yang didukung untuk menemukan jalan keluar atas kesulitan dalam membuat, mendistribusikan dan menggolong-golongkan setiap penugasan tanpa kertas. Perangkat lunak ini telah diluncurkan sebagai keistimewaan Google Apps for Education dan diterbitkan kepada secara meluas sejak 12 Agustus 2014. Google Classroom merupakan salah satu dari beberapa layanan Google untuk mengisyaratkan kepada lembaga-lembaga pendidikan agar beralih ke sistem tanpa kertas. Pembuatan dan pemberian tugas dapat dilakukan dengan membawa Google Drive sambil menggunakan gmail untuk membuat penerimaan di ruang kelas Google. Siswa dapat diundang ke ruang kelas dengan beberapa cara melalui basis data lembaga, melalui kode pribadi yang kemudian dapat ditambahkan di dalam antarmuka siswa atau dengan didatangkan secara lengkap dari Sistem Pengelolaan Keterangan Sekolah (Sistem Manajemen Informasi Sekolah). Penyampaian info tugas yang diberikan pendidikan akan disampaikan kepada siswa melalui akun Gmail.11 Dengan demikian, akan memudahkan para pendidik dalam menginformasikan ujian tanpa harus bertemu ataupun menghubungi satu persatu.

Namun pada tahun 2014 sampai dengan 2016 ternyata layanan ini tidak diperuntukkan untuk kalangan umum, tetapi hanya untuk sekolah/lembaga yang melakukan kerjasama dengan pihak google. Pada tahun 2017 akhirnya google memutuskan untuk memberikan akses tanpa batas kepada penggunanya untuk menggunakan google classroom dengan menggunakan akun pribadi sehingga para pendidik mendapatkan keuntungan atas keputusan tersebut. Fitur yang disediakan adalah; penugasan disimpan dan dinilai pada rangkaian aplikasi produktivitas google oleh pendidik, komunikasi antar pendidik dan siswa, time-cost, archive course, mobile application, dan privasi. ${ }^{12}$

10 Fransiskus Ivan Gunawan dan Stefani Geima Sunarman, "Pengembangan Kelas Virtual Dengan Google Classroom Dalam Keterampilan Pemecahan Masalah (Problem Solving) Topik Vektor Pada Siswa SMK untuk Mendukung Pembelajaran," 2018, h. 341.

11 "Google Classroom," dalam Wikipedia bahasa Indonesia, ensiklopedia bebas, 11 Desember 2017, https://id.wikipedia.org/w/index.php?title=Google_Classroom\&oldid=13433085.

12 Vicky Dwi Wicaksono dan Putri Rachmadyanti, "Pembelajaran Blended Learning Melalui Google Classroom di Sekolah Dasar," 2017, h. 516-517. 


\section{Simulasi Penggunaan Fitur Google form}

Tampilan depan (Masuk menggunakan akun Gmail)

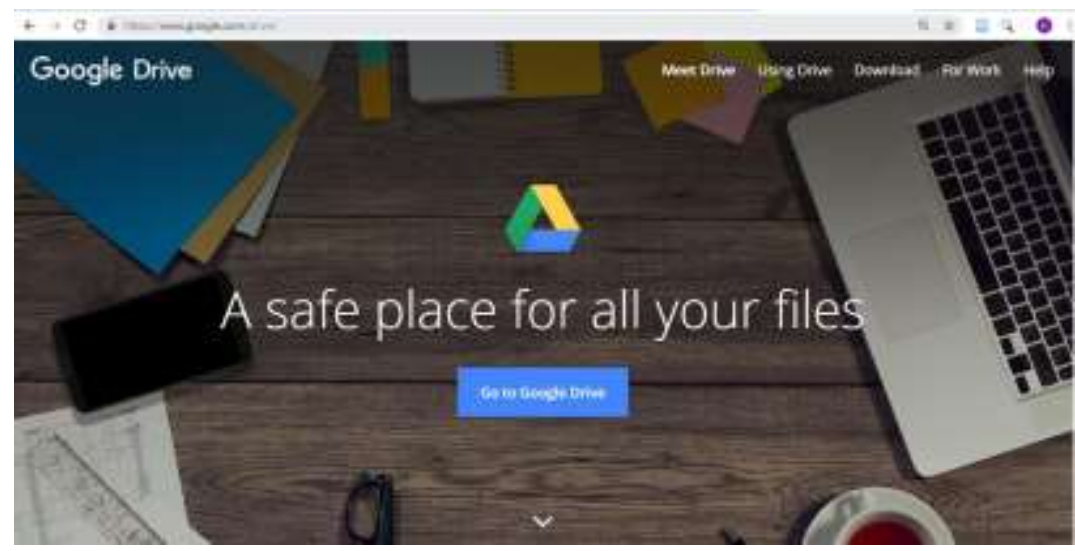

\section{Menu Google form}

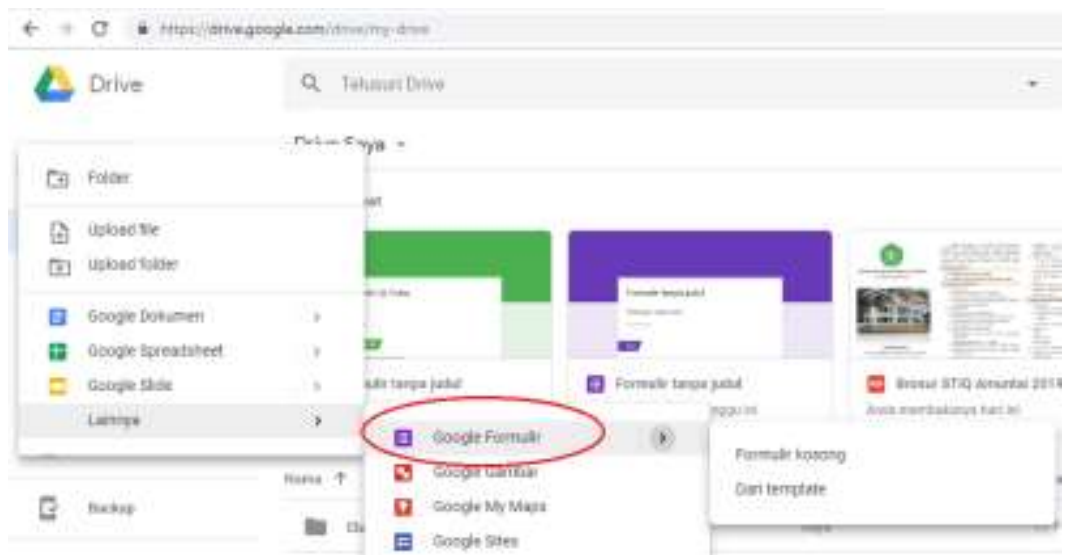

Tampilan Google form

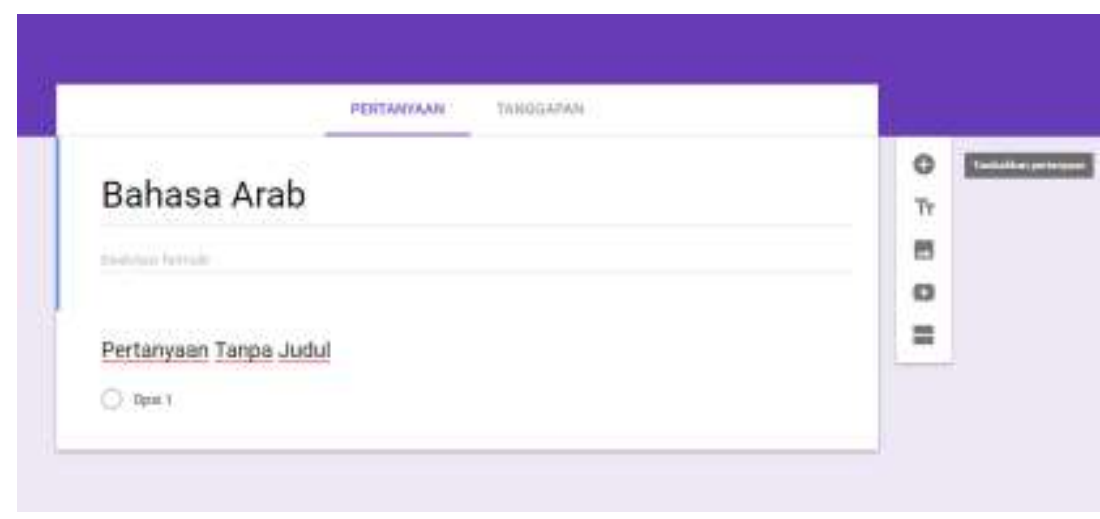




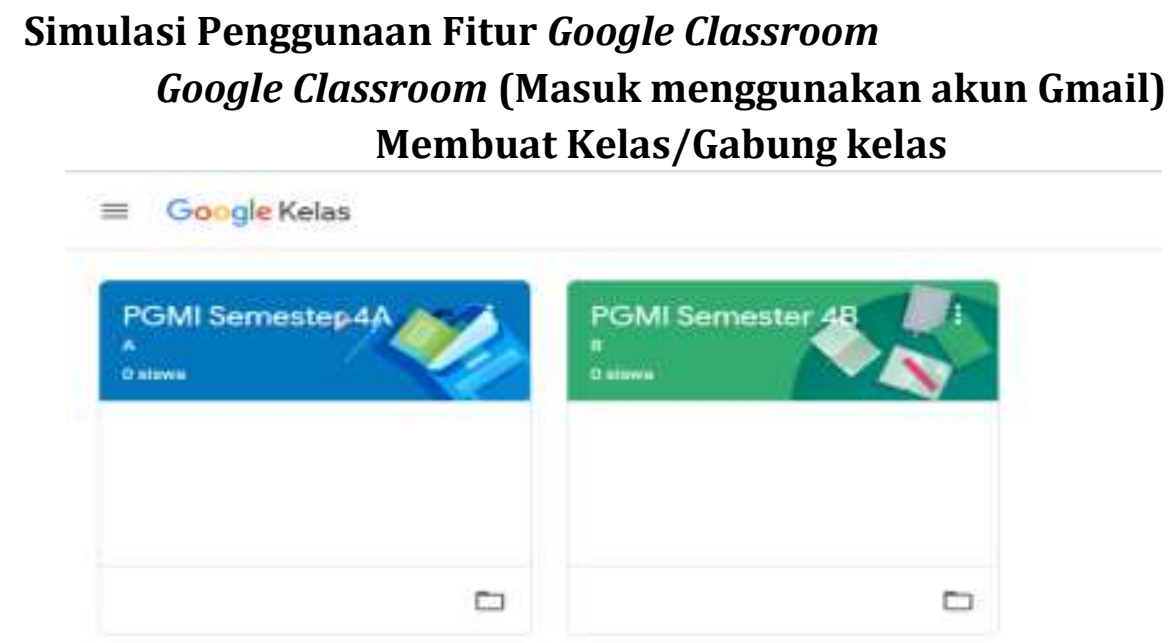

\section{Kelas dan Kode Kelas}

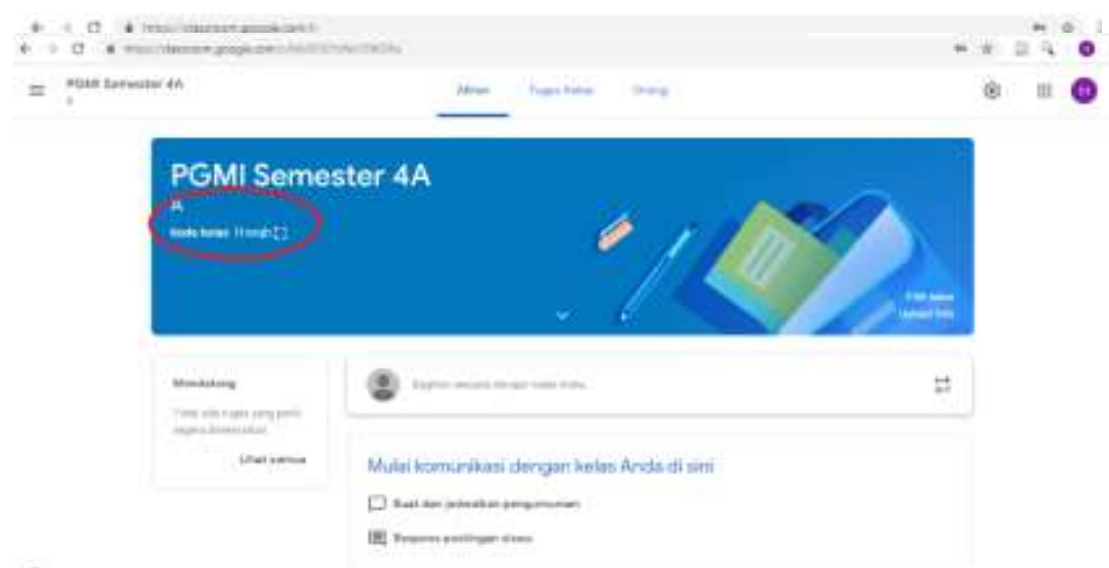

\section{Membuat Tugas}

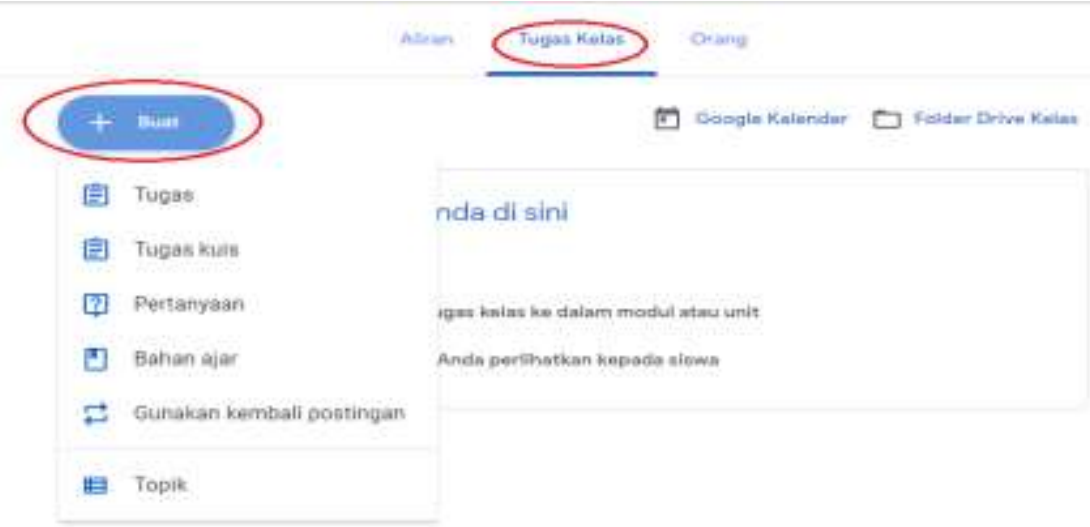




\section{Penugasan Jadwal (Bisa diatur waktunya)}

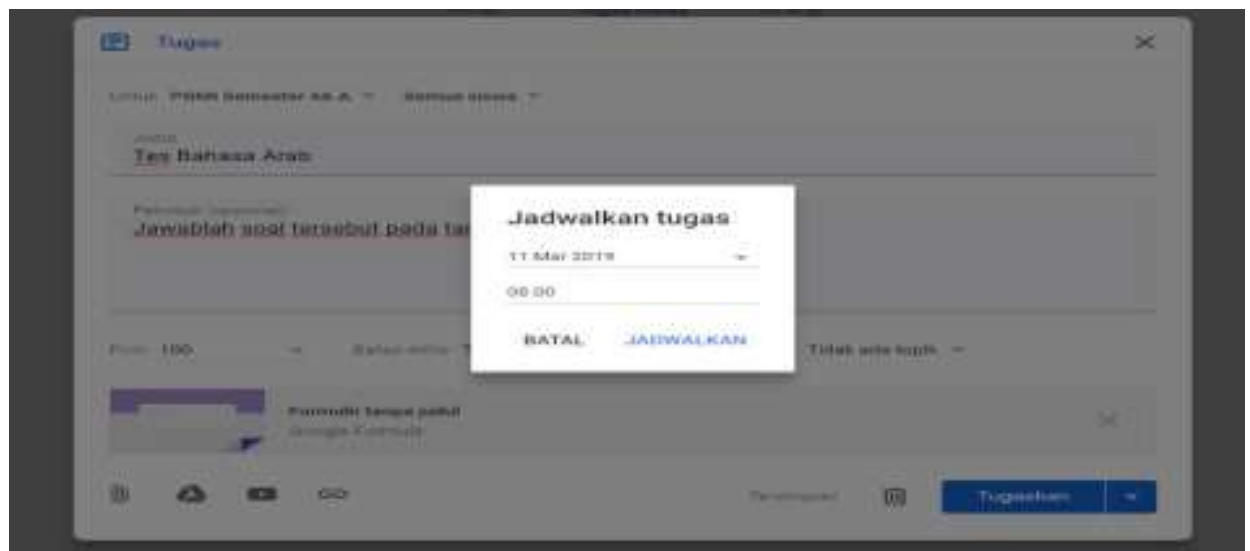

\section{PEMBAHASAN DAN ANALISIS HASIL PENELITIAN}

Google form dan google classroom dianggap penting untuk diketahui dan digunakan karena penggunaannya tidak berbasis instalasi listrik ataupun kabel, sehingga memudahkan pelaksanaan UTS, latihan maupun tes dan lainnya. Kemudahan lainnya yang dirasakan adalah, cepatnya proses pembuatan dan pelaksanaan tes serta tidak menggunakan hosting pribadi melalui komputer sebagai hard drive utama, dan menyalurkan menggunakan kabel LAN atau wajib menggunakan jaringan yang sama, sedangkan Google form dan google classroom menggunakan hosting cloud secara gratis dan mudah penggunaannya. ${ }^{13}$

\section{Kolaborasi Google form dan Google Classroom}

Dengan menggunakan kedua aplikasi ini ataupun salah satunya, kita dapat membuat dan melaksanakan tes dimanapun tanpa terikat dengan tempat dan pembiyaan yang terlalu besar. Pada dasarnya google form dan google classroom memiliki perbedaan mendasar; google form berfungsi sebagai instrumen seperti peletakan soal dan penilaian sedangkan google classroom sebagai media untuk berkomunikasi dengan siswa berupa info pelaksanaan dan materi tes. Google form dan google classroom bisa dikolaborasikan penggunaannya dengan memfokuskan google classroom sebagai pemberian info tes, tugas, dan soal, sedangkan google form untuk pembuatan butir-butir

\footnotetext{
13 Wawancara dengan Dosen Program Studi Pendidikan Guru Madrasah Ibtidaiyah pada Tanggal 16 Maret 2019
} 
soal yang diujikan. Di dalam google classroom juga berfungsi untuk pengelompokan nilai sesuai dengan kelasnya, contoh kelas $5 \mathrm{~A}$, maka di sana hanya terdapat nilai dari orang-orang yang bergabung pada kelas 5A tanpa harus milih satu persatu. Untuk proses kolaborasi, soal dibuat di google form yang kemudian diumumkan menggunakan google classroom. Peng-input-an google form bisa dilaksanakan pada kolom tugas pada google classroom dengan menggunakan fitur upload file (fitur upload file ini juga dapat menggunakan file selain google form seperti office word). ${ }^{14}$

Kelebihan kolaborasi antara keduanya adalah google classroom tidak memiliki fungsi sebagai survei yang berformat pilihan ganda serta penilaian secara langsung, maka google form sebagai pelengkap fitur yang tidak ada pada aplikasi tersebut. Dan karena keduanya terintegrasi, maka ketika selesai mengisi jawaban dan sending data dari peserta tes, maka akan ada laporan pada pendidik sebagai pengelola google classroom bahwa siswa tersebut sudah melakasanakan dan mengirim tugas. ${ }^{15}$

\section{Pembuatan Akun}

Mengingat kedua aplikasi ini dikeluarkan dan teringrasi dengan google maka proses pembuatan akunya pun menggunakan gmail yang juga dimiliki oleh perusahaan google. Jika dilihat secara umum para pendidik sangat mampu untuk melakukan pembuatan email dan masuk ke program aplikasi ini, karena prosesnya juga mudah dan simpel. ${ }^{16}$ Kendala yang didapat dalam pelaksanaan google classroom dan google form tidak semuanya mempunyai email dari gmail. ${ }^{17}$ Dan solusinya adalah dengan memberikan kewajiban untuk membuat email karna sifatnya gratis. Dan siswa menunjukkan sikap welcome terhadap perubahan sistem yang ada. Dengan banyaknya fitur dan kemudahan, masih beberapa pendidik yang menggunakan kedua aplikasi tersebut dan belum semuanya, mengingat rata-rata hanya dosen muda yang tidak asing dengan penggunaan internet dan aplikasi google. Dan latarbelakang yang paling mendasari terkendalanya pelaksanaan evaluasi online, (1) jarang menggunakan internet sebagai media (2) belum mengetahui fitur-fiturnya dan belum

\footnotetext{
14 Wawancara dengan Dosen Program Studi Pendidikan Guru Madrasah Ibtidaiyah pada Tanggal 16 Maret 2019

15 Wawancara dengan Dosen Program Studi Pendidikan Guru Madrasah Ibtidaiyah pada Tanggal 16 Maret 2019

16 Wawancara dengan Dosen Program Studi Pendidikan Guru Madrasah Ibtidaiyah pada Tanggal 16 Maret 2019

17 Wawancara dengan mahasiswa pada tanggal 26 Februari 2019
} 
dipraktikkan, sehingga harus dilaksanakan pelatihan untuk mengatasi gagap teknologi. 18

\section{Pembuatan Soal dan Pelaksanaannya}

Untuk kendala pembuatan soal tidak ada secara teknis. Dan ketika terjadi kesalahan dalam membuat soal sebagai contoh; kesalahan dalam pemberian soal, maka dapat dilakukan perubahan dengan fitur edit tanpa merubah link yang sebelumnya sudah disebar. Dan siswa pun tidak akan merasa berat dan komplain terhadap perbaikan yang ada, karena prosesnya cepat dan mudah tanpa harus menunggu lama, berbeda ketika menggunakan kertas dan informasi secara manual.

Untuk proses pengisian jawaban oleh mahasiswa tanpa pelatihan tetap dapat dilaksanakan dengan baik, kecuali untuk pendidik yang ingin membuat soal dan desain dianjurkan mengikuti pelatihan atau belajar secara otodidak, mengingat ada beberapa langkah yang harus dijalankan. Kendala yang dihadapi dalam pembuatan soal bahasa Arab tidak adanya fitur listening yang diujikan untuk tes kompetensi mendengar baik dari google form maupun google classroom. Sedangkan penulisan soal dalam bentuk bahasa Arab dilakukan dengan menggunakan dua cara (1) penulisan manual (2) menggunakan foto. ${ }^{19}$

Secara manual, ada beberapa kendala yang dihadapi berupa baris bahasa Arab yang terlihat kecil jika menggunakan komputer dan terlihat jelas pada handphone. ${ }^{20}$ Untuk mengatasi kendala pembacaan soal melalui komputer/laptop dilakukan zoom layar dan kendala lainnya format fontnya hanya tersedia satu saja tanpa bisa dirubah ke format lain seperti traditional arabic sehingga tulisan tidak selalu baik dan enak dipandang. ${ }^{21}$

Menggunakan foto dalam meng-upload butir-butir soal memberikan kemudahan untuk mengatasi kekurangan penulisan manual, namun sedikit ribet dengan cara membuat soal di aplikasi Microsoft word terlebih dahulu, kemudian melakukan screenshot untuk setiap soal dan di upload pada fitur google form. Jika memiliki waktu yang banyak maka akan lebih bagus menggunakan foto karena bentuk tulisan lebih bebas dan dapat disesuaikan

18 Wawancara dengan dosen Program Studi Pendidikan Bahasa Arab pada Tanggal 25 Maret 2019

19 Wawancara dengan dosen Program Studi Pendidikan Guru Madrasah Ibtidaiyah pada Tanggal 16 Maret 2019

20 Wawancara dengan mahasiswa pada tanggal 26 Februari 2019

21 Wawancara dengan dosen Program Studi Pendidikan Guru Madrasah Ibtidaiyah pada Tanggal 16 Maret 2019 
jenisnya menurut keinginan pendidik. Namun jika waktu yang dimiliki terbatas maka akan dipilih yang secara manual.

\section{Penentuan Waktu Tes}

Kemudahan lainnya dalam pelaksanaan tes, pendidik tidak harus mengikuti proses ujian dan bisa ditinggal tanpa hadir sedikit pun ke kelas untuk memberikan arahan, karena semua data sudah diumumkan melalui google classroom. Dan pelasanaan bisa diatur waktunya, walaupun pengumuman ujian dan link sudah disebar pada tanggal 1 maret 2019 namun pelaksanaan tes pada tanggal 20 maret, maka tes akan tetap dilaksanakan dan diisi pada tanggal 20 maret jika waktu pengerjaan diatur hanya pada tanggal tersebut. Demikian pula untuk batas waktu berakhirnya, sebagai contoh di mulai jam 08.30 WITA dan selesai jam 10.00 WITA, maka ketika jam tepat jam 10.00 WITA dan siswa belum melakukan sending data jawaban maka akan ada keterangan bahwasanya yang bersangkutan terlambat mengumpul jawaban, bahkan bisa diatur untuk penolakan upload jawaban. Sehingga jika ditinggal pun tidak akan terjadi masalah, karena keterlambatan siswa dalam mengumpul jawaban juga akan diketahui pendidik tanpa harus bertanya kepada peserta yang mengikuti tes. Penentuan waktu di google form bisa diatur waktu mulai tes dan masa berakhirnya tes sedangkan google classroom hanya terdapat diakhir, namun keduanya tetap dapat dikolaborasi untuk mendapatkan berbagai macam kemudahan, termasuk di dalamnya pengelompokan hasil tes. ${ }^{22}$

\section{Pengisian dan Pengiriman Hasil Jawaban}

Pengisian untuk sending data jawaban bisa diatur sekali dan berkali kali, dan keduanya bisa digunakan tergantung keperluan, jika digunakan untuk pengayaan dan latihan bisa diatur berkali-bali untuk proses edit, namun jika yang diinginkan adalah tes untuk penetapan skill akhir hanya diatur satu kali pengisian jawaban. Sedangkan semua data-data tes tersimpan di google drive, dan bisa dijadikan metadata pendidik dan bank soal. ${ }^{23}$

Untuk google form semakin banyak soal maka layar akan bergerak semakin lambat dan paling banyak cuman berkisar 50 soal, karena dengan membuat soal berjumlah 150 ternyata memperlambat proses perpindahan

\footnotetext{
22 Wawancara dengan Dosen Program Studi Guru Madrasah Ibtidaiyah pada Tanggal 16 Maret 2019

${ }^{23}$ Wawancara dengan Dosen Program Studi Guru Madrasah Ibtidaiyah pada Tanggal 16 Maret 2019
} 
antar gambar dan terasa patah-patah karena programnya menjadi berat dengan banyaknya soal, dan untuk mengatasi kelemahan tersebut, google menyediakan fitur tambah halaman, jadi soal yang tadinya berjumlah 150 soal, akan dibagi menjadi 3 halaman sehingga lebih ringan dalam proses pengisian dan pengeseran kursor layar. ${ }^{24}$

\section{Penilaian}

Perbedaan mendasar pada google form dan google classroom sangat terlihat pada proses penilaian. Pada google form nilai akan keluar secara otomatis sesuai dengan indikator yang kita buat dalam proses pembuatan tes. Dan google classroom nilai tidak akan keluar secara otomatis dan harus diisi secara manual. Namun dari segi pengelompokan nilai, (1) google form, mengingat google form tidak memiliki kelas dan sifatnya umum, maka nilaipun akan terkumpul secara umum tanpa katagori sehingga harus dipilah dan dikumpulkan sendiri oleh pendidik, (2) dan google classroom pengelompokan nilai akan muncul secara otomatis, namun pemberian nilai harus diberikan secara manual dan siswa harus menunggu sampai nilai tersebut di upload dan diperiksa oleh pendidik, maka penggabungan keduanya akan menghasilkan kemudahan yang akan memudahkan para pendidik dalam proses evaluasi. ${ }^{25}$

\section{ANALISIS}

Apapun yang dinilai yang berhubungan dengan input, proses dan penilaian harus menyediakan informasi sesungguhnya dan autentik. ${ }^{26}$ Dengan adanya evaluasi secara cepat dan penilaian yang muncul setelah jawaban dikirm akan menghasilkan objektifitas dalam proses pendidikan tanpa rekayasa dalam pemberian nilai.

Melihat dari hasil wawancara dan observasi yang ada, menunjukkan bahwa penerapan tes berbasis google form dan google classroom tidak memiliki masalah yang sangat signifikan, beberapa masalah yang dihadapi adalah (1) mahasiswa tidak memiliki akun gmail (2) perlunya training untuk kalangan pendidik.

\footnotetext{
${ }^{24}$ Wawancara dengan Dosen Program Studi Guru Madrasah Ibtidaiyah pada Tanggal 16 Maret 2019

25 Wawancara dengan dosen Program Studi Pendidikan Bahasa Arab pada Tanggal 20 Maret 2019

${ }^{26}$ Muri Yusuf A, Asesmen dan Evaluasi Pendidikan (Jakarta: Kencana, 2017), h.40.
} 
Untuk pembuatan akun baik untuk kalangan pendidik dan siswa tidak akan menjadi masalah, mengingat google form dan google classroom terintegrasi dengan aplikasi google berupa akun gmail. Namun untuk proses pelaksanaan training pendidik, ada beberapa hal yang perlu diperhatikan dalam pembentukan training dengan melakukan program pengenalan

Program pengenalan bertujuan untuk meningkatkan persentasi keberhasilan program agar tercapai sesuai dengan yang diharapkan sehingga margin of error tidak cenderung banyak dan sulit diatasi, pengenalan yang dilaksanakan dalam proses tes berbasis online menggunakan media google form dan google classroom terbagi menjadi dua bagian, (1) pengenalan berfokus kepada pendidik, (2) pengenalan berfokus kepada siswa.

Pengenalan berfokus kepada pendidik dilaksanakan dengan menggunakan pelatihan-pelatihan mengingat fitur dalam menggunakan google form dan google classroom bervariasi tergantung keperluan yang diinginkan oleh pendidik dalam melaksanakan evaluasi. Sedangkan pengenalan yang difokuskan kepada siswa, dilakukan melalui pengenalan di dalam kelas mengingat siswa hanya menerima data dan sending data, berbeda dengan pembuat desain bahan tes yang harus memilih desain, mengisi soal, penilaian dan penyebaran data.

Yang perlu diperhatikan dalam melaksanakan pengenalan dan training pendidik sebagai berikut:

a. Melakukan perencanaan program dengan melakukan analisis keperluan yang harus disediakan, baik dari segi waktu, tempat dan pengenalan awal yang disesuaikan dengan kemampuan menangkap pendidik, ada beberapa tantangan yang dihadapi yaitu dengan terbaginya peserta training menjadi 2 bagian, (1) kaum tua, dan (2) kaum muda. (1) Mengingat google form dan google classroom merupakan teknologi yang berfokus kepada layanan internet walaupun bukan teknologi yang terlalu baru, namun untuk kaum tua program ini merupakan program yang harus dipelajari secara detail dan fokus, mengingat adanya perbedaan di antara kaum tua dengan kaum muda dari segi penggunaan internet (2) Untuk kaum muda, tentunya akan lebih mudah untuk dilaksanakan dengan terbiasanya hidup dan bersosialisasi menggunakan internet dalam kehidupan sehari-hari. 
b. Menentukan peserta training sesuai dengan kemampuannya dan diperkirakan mampu untuk melaksanakan evaluasi menggunakan google form dan google classroom setelah mengikuti training

c. Menentukan jenis dan materi pelatihan yang sesuai dengan peserta yang telah mendaftar sehingga mudah untuk dipahami dan dimengerti

d. Pelaksanaan training, walaupun fitur google form dan google classroom merupakan landasan awal para pendidik untuk melaksanakan evaluasi yang lebih hebat dan menyenangkan, maka tidak ada salahnya melaksanakan training, namun akan lebih baik tetap memperhatikan kaum muda dan kaum tua yang tentunya pemahaman kaum muda akan lebih cepat untuk menguasai dibandingkan kaum tua, oleh karena itu akan lebih baik jika kaum tua memiliki kaum muda setidaknya 1 orang di sebelahnya agar lebih mudah bertanya dan mengikuti training.

Adapun kelemahan di bidang alat elektronik dengan tidak supportnya handphone atau kouta yang tidak memadai, dapat dipecahkan menggunakan tes secara bergantian dan pihak lembaga atau dosen menyediakan fasilitas internet, mengingat hampir semua lembaga pendidikan sudah mempunyai fasilitas internet, namun jika ternyata tidak ada tetap dapat maka dapat digunakan cara lain berupa menggunakan hotspot seluler atau menggunakan modem, dan pelaksanaan tes online tidak akan menguras terlalu banyak kouta mengingat ukuran file yang diujikan relatif sedikit.

Ada beberapa kebutuhan siswa yang dapat didapat dengan adanya evaluasi online: kebutuhan akan rasa aman, dan memiliki (merupakan dorongan untuk mendapatkan rasa aman, tentram, kepastian dan jaminan), kebutuhan akan rasa harga diri (kebutuhan individu untuk merasa berharga dalam hidupnya, kebutuhan ini meliputi: penghargaan diri sendiri, seperti percaya diri, hasrat untuk memperoleh kompetensi, kekuatan pribadi dan kemandirian), dan kebutuhan akan aktualisasi diri (kebutuhan untuk menjadi orang yang sesuai dengan keinginan dan potensi dirinya). ${ }^{27}$ yang artinya dengan proses evaluasi instan dan cepat pelaksanaannya dan penilaiannya akan menghasilkan rasa aman dan ketenangan dalam melaksanakan tes, sehingga pendidik pun dapat melaksanakan tugasnya sebagai tester yaitu; menentukan kemajuan pendidikan dan memperoleh informasi berupa umpan balik bagi penyempurnaan pendidikan. ${ }^{28}$

27 Desmita, Psikologi Perkembangan Siswa (Bandung: Rosda, 2012), h.63-65.

${ }^{28}$ Anas Sudijono, Pengantar Evaluasi Pendidikan (Jakarta: Raja Grafindo Persada, 2016), h.2. 


\section{SIMPULAN}

Dengan berbagai macamnya kemudahan yang didapat dari google form dan google classroom, baik dari segi pembuatan akun, pembuatan soal dan penilaian yang bisa didapat secara instan, maka tidaklah berlebihan jika penggunaan kedua aplikasi tersebut sangat membantu jalannya proses evaluasi menuju ke arah yang lebih baik sehingga terciptanya evaluasi yang aman, nyaman dan menyenangkan. Dan penerapan media online berbasis google form dan google classroom dapat dikolaborasikan untuk mencapai hasil yang maksimal dan terstruktur, yang mana google form berfungsi sebagai data-data soal dan google classroom sebagai penyimpanan data nilai. Untuk proses evaluasi pengajaran bahasa Arab, (1) pendidik memberikan pengenalan dasar tentang google form dan google classroom sebagai langkah awal, kemudian melakukan persiapan tes yang dapat dilaksanakan dengan dua cara, melakukan input secara langsung menggunakan fitur ketik aplikasi dan menggunakan foto agar bentuk tulisan lebih mudah dibaca, untuk penilaian dilaksanakan dengan memberikan poin dan membatasi waktu pengerjaan dan waktu selesai, (2) Siswa, mendapatkan pengenalan awal sebagai langkah penggunaan aplikasi, pembuatan akun gmail, pelaksanaan tes dan mendapatkan nilai tes setelah mengirim jawaban.

Dan kendala yang dihadapi dalam penerapan ini dan mengatasinya adalah (1) Pendidik, pelaksanaan terkendala oleh sebagian pendidik yang belum terlalu menguasai aplikasi google form dan google classroom dan perlu adanya pelatihan yang jelas dan terstruktur terutama untuk kaum tua yang yang belum membiasakan diri terhadap internet, (2) Siswa, ada beberapa siswa yang belum mengetahui dan merasakan kemudahan dari aplikasi ini sehingga merasa berat untuk mengikuti perkembangan yang ada, sehingga diperlukan pengenalan-pengenalan dan pemahana terlebih dulu agar peserta merasa tertarik untuk menggunakannya.

\section{SARAN}

Dengan berkembangnya teknologi, maka mau tidak mau para pendidik pun harus mengikuti perkembangan tersebut, agar tidak terjadi gagap teknologi. Namun para pendidik juga tidak boleh menafikan bahwa memang ada beberapa 
siswa atau bahkan beberapa orang merasa tidak ingin dan berat untuk mengikuti perkembangan yang ada karena belum terbiasa dan belum adanya info dan pengetahuan tentang perkembangan tersebut. Oleh karena itu sebelum melaksanakan proses evaluasi online harus dilaksanakan pengenalanpengenalan yang bertujuan untuk memudahkan siswa dalam menjalani proses pelaksanaan tersebut. Penggunaan google form dan google classroom berfungsi sebagai jalan awal untuk menuju proses evaluasi yang lebih mudah, bermakna dan sesuai dengan perkembangan zaman.

\section{Daftar Pustaka}

A, Muri Yusuf. Asesmen dan Evaluasi Pendidikan. Jakarta: Kencana, 2017.

Batubara, Hamdan Husein. "Penggunaan Google form Sebagai Alat Penilaian Kinerja Dosen di Prodi PGMI Uniska Muhammad Arsyad Al Banjari." Jurnal Al Bidayah 8, no. 1 (2016).

Desmita. Psikologi Perkembangan Siswa. Bandung: Rosda, 2012.

“Google Classroom." Dalam Wikipedia bahasa Indonesia, ensiklopedia bebas, 11 Desember2017.

https://id.wikipedia.org/w/index.php?title=Google_Classroom\&oldid= 13433085.

“Google forms." Dalam Wikipedia, 21 Februari 2019. https://en.wikipedia.org/w/index.php?title=Google_Forms\&oldid=884 340113.

Gunawan, Fransiskus Ivan, dan Stefani Geima Sunarman. "Pengembangan Kelas Virtual Dengan Google Classroom Dalam Keterampilan Pemecahan Masalah (Problem Solving) Topik Vektor Pada Siswa SMK untuk Mendukung Pembelajaran," 2018.

Iqbal, Muhammad, Rosramadhana Rosramadhana, Bakhrul Khair Amal, dan Murni Eva Rumapea. "Penggunaan Google forms Sebagai Media Pemberian Tugas Mata Kuliah Pengantar Ilmu Sosial." JUPIIS: JURNAL PENDIDIKAN ILMU-ILMU SOSIAL 10, no. 1 (2018): 120-27.

KOMINFO, PDSI. "Pengguna Internet Indonesia Nomor Enam Dunia." Website Resmi Kementerian Komunikasi dan Informatika RI. Diakses 10 Maret 2019. https://kominfo.go.id:443/content/detail/4286/penggunainternet-indonesia-nomor-enam-dunia/0/sorotan_media.

Majid, Abdul. Strategi Pembelajaran. Bandung: Rosda, 2013.

Mashurwati, Yuyun. "Penerapan inventory tes gaya belajar remaja dengan aplikasi google form, media sosial serta pengembangan program layanan bimbingan dan konseling terkait." Jurnal EDUCATIO: Jurnal Pendidikan Indonesia 4, no. 1 (2018): 1-6.

Patria, Lintang, dan Kristianus Yulianto. "Pemanfaatan Facebook untuk Menunjang Kegiatan Belajar Mengajar Online Secara Mandiri," 2011. 
Ramadhani, Dony Ahmad. "EVALUASI KETERAMPILAN BERBICARA DALAM PEMBELAJARAN BAHASA ARAB." Al Qalam: Jurnal Ilmiah Keagamaan dan Kemasyarakatan, 2018.

Setemen, Komang. "Pengembangan Evaluasi Pembelajaran Online." Jurnal Pendidikan dan Pengajaran 43, no. 3 (2010).

Sudijono, Anas. Pengantar Evaluasi Pendidikan. Jakarta: Raja Grafindo Persada, 2016.

Wicaksono, Vicky Dwi, dan Putri Rachmadyanti. "Pembelajaran Blended Learning Melalui Google Classroom di Sekolah Dasar," 2017. 